\title{
SOCIAL MEDIA INFLUENCE ON PUBLIC OPINION AND YOUTH BEHAVIOR
}

\section{Husak Olviia ${ }^{1}$ \\ Fiialka Svitlana ${ }^{2}$}

DOI: http://dx.doi.org/10.30525/978-9934-571-27-5_17

\begin{abstract}
Main objective. The article deals with the key factors of the virality of media content in social networks and technical university students' media literacy in social networks. Methodology. We analyzed the concept of virality and generalized the reasons that affect the popularity of the information posted in social networks. The three main groups of virality factors were singled out: content (its subject and form), the audience and the specific character of a social network. We have also analyzed the content of the three most popular Ukrainian media in Facebook: "Ukrayinska Pravda", "Hromadske TV" and "TSN" to define the virality factors in modern Ukrainian conditions. The study was conducted in National Technical University of Ukraine "Igor Sikorsky Kyiv Polytechnic Institute" (Kyiv, Ukraine). In addition quantitative analysis of 10 closed ended responses, qualitative analysis of 5 open ended responses and focus group discussion experts were done. The study population included students $(\mathrm{n}=1100)$ of the fourth course and 10 experts (professors in the fields of engineering ( 5 persons), pedagogics ( 2 persons) and social communications (3 persons)). Results and conclusions. Due to the study results there are few most popular content topics (politics, war in eastern Ukraine and basic needs) that cause the virality of information. Given the specificity of the algorithm for ranking posts in Facebook news line, we traced the reasons for the popularity of certain materials, which are caused by the situation in the country, emotions, induced by the publication, type of content and time of users' activity in the social network. The survey questionnaire captured the attitudes of students about the social networks and their role in everyday life and professional development, found out what
\end{abstract}

\footnotetext{
${ }^{1} \mathrm{PhD}$ in Social Communications Sciences, Senior Lecturer,

National Technical University of Ukraine "Igor Sikorsky Kyiv Polytechnic Institute", Ukraine

${ }^{2} \mathrm{PhD}$ in Social Communications Sciences, Associate Professor,

National Technical University of Ukraine "Igor Sikorsky Kyiv Polytechnic Institute", Ukraine
} 
percentage of students uses social networks for educational purposes, revealed whether the students trust to information from posts in social networks, as well as their reactions to messages. The qualitative analysis found out the reasons why students use or do not use social networks for their educational purposes, why are they joining or are not joining social networking groups that discuss political topics, why do they react or do not react on insults in social networks, why do they always (do not always) critically analyze information in social media, why do they think it is necessary (not necessary) to implement media literacy courses in the university. The focus group discussion revealed how social networks have influenced education, factors impacting social networks use for education, how the experts foresee the role of social networks in education and collected opinions about the media literacy as a part of engineering curriculum. Overall the observations found out weak spots in students' media literacy. Thus, it is necessary to implement media education in technical universities to teach students to become media "literate" in order to participate responsibly in the new century society, analyze media information critically and recognize misinformation.

\section{Introduction}

Technological peculiarities of the development and functioning of the worldwide web and communication technologies led in general to significant differences in the processes and methods of attracting and establishing the audience of offline and online media. In recent years there is also a huge increase of the role of social networks in the formation of both the content and the audience of modern mass media. Instant update of information in social networks, an increase of the number of information sources and other peculiarities of the new media functioning make it possible to speak about informational overproposition which consequently gives rise to the competition between online media and social networks, causing not only the improvement of quality and presentation of content, but also the reduction of the audience of specific media websites. Therefore, one of the tools to increase the traffic from social networks and successful media SMM-promotion is the virality of content. In addition, viral content can influence essentially public opinion and manipulate public conscience in terms of hybrid warfare and lack of clear mechanisms of informational confrontation. Using the factors of information popularity on social networks, 


\section{Husak Olviia, Fiialka Svitlana}

particularly emotions it evokes, the submission style, time of publication, subject matter, and taking into account the principles of ranking reports by particular social networks, Ukrainian media can secure an effective source of audience, the popularity in a new media space and become a means of countering hybrid aggression in social networks.

But to be engaged and critical media consumers, we need to develop skills and habits of media literacy. In order to participate responsibly in the new century society and navigate through an increasingly complex media landscape, it is important to begin the process of media literacy education in childhood and continue throughout life.

Many local and foreign researchers studied media in social networks. Having analyzed the articles from the "Times", American scientists J. Berger and K. Milkman single out a number of content features, which affect its virality, in particular readers' emotions the content causes. However, there is a lack of analysis of the peculiarities of preparing the virality content for social networks in Ukrainian reality. This fact determines the relevance of our study. The aim of this paper is to define the factors of content virality of Ukrainian media in social networks under conditions of hybrid warfare and to explore the general attitude and perceptions of students of technical specialties at the last year of bachelor program about social networks and their role in professional development.

Methods of the study. The task required a combination of general and specific scientific methods - theoretical and empirical. In particular, we used the methods of generalization and terminological analysis to clarify the definitions of the term "virality" and "virality content". Analytic and synthetic method allowed us to single out the virality factors of the content and to get an idea of the whole system of measures applied for the promotion of information on social networks. The method of observation and measurement was used for collecting the actual source material for the theoretical study of the factors of virality content under Ukrainian conditions; the comparison method made it possible to define the features of popularization of information under special circumstances, such as during the hybrid warfare. The method of content analysis was used for in-depth study of text messages of social networks in order to select the indicators, which allowed us to interpret the study results into specific recommendations concerning the promotion of media content under present-day comditions. 
To understand the media literacy level of students of technical specialties the questionnaire based study was conducted in National Technical University of Ukraine "Igor Sikorsky Kyiv Polytechnic Institute" (Kyiv, Ukraine). Study sample consists of 1100 students. 8 students aren't registered in any social network and 34 are registered but they visit networks twice a month or more rarely. So really 1058 students were polled: 925 males $(87.43 \%)$ and 133 females $(12.57 \%)$. They had an average age of 24.5 years, with a range of 20 to 29 years. The survey questionnaire (10 closed ended and 5 open ended items) and Focus group discussion (FGD) captured the perceptions and attitudes of students about social networks. Th internal consistency of closed ended items were calculated. The study population was briefed about the nature and purpose of study. The survey questionnaire was sought from all the 1058 students. The students were answered the questionnaire in a lecture classes. The survey was followed by a structured FGD $(n=10)$. The participants of FGD were carefully selected. The selection of FGD participants were based on the representation of professors in the fields of engineering ( 5 persons), pedagogics ( 2 persons) and social communications (3 persons). The FGD, which lasted for two hours, was conducted by two members of Publishing and Printing Institute, one as a facilitator, and other who recorded the discussion verbatim. The FGD was an attempt to find out attitudes and perceptions regarding social networks and its potential role in engineering education.

Quantitative data was analyzed by percentage distribution and Qualitative data by categorization. The transcripts of the focus group were collated and categorized.

\section{The factors of the content virality of Ukrainian media in social networks}

Virality content is the publications that have the ability to the virus-like self-replication, i.e. to the natural replication of materials by the users of social networks. The audience, uses the "sharing" buttons (e.g., "tell your friends", "share", "tweet"), for spreading interesting publications [1]. The researchers of Internet communication explain the phenomenon of virality by Metcalfe law, due to which the network utility is proportional to the square of the number of its users [2]. According to this law, the reason of content virality may be in the increasing number of users interested in it, and as a result the value of the content increases. 


\section{Husak Olviia, Fiialka Svitlana}

However, it should be noted that the phenomenon of virality is more complex and versatile. In general, we can talk about three major components of virality factors:

- content - its features, form, subject area, etc. (for example, an article consisting of 10000 signs will be less popular among users than a striking infographics on the same subject);

- audience (the users of social networks share only the information that will be interesting or useful among their friends, wanting to get a "bonus" in return - "like" thanks, admiration, etc.);

- the peculiarities of social network that influence the form and type of content, as well as the activitiy and characteristics of the audience (the best hours for posting, peculiarities of ranging materials in the news line, etc.).

While considering the first factor of virality - the very content - one should mention the results of the studies of American scientists J. Berger and K. Milkman, who have analyzed nearly 7,000 articles, published in "Times" from August 30 to November 30, 2008 to find out the materials that have been most frequently shared by users. Having taken into account such factors as time of article posting, the author's popularity, author's sex, length and complexity of the material, J. Berger and K. Milkman revealed two characteristics which define the virality of an article. They found out that the popularity of the material depends primarily on how positive its basic idea is and how strong reader's emotions it can evoke [3]. In general there are several features that affect virality of materials in social networks:

- emotions the publication causes. More emotional materials are being more frequently shared in social networks. Positive emotions contribute to popularity more than negative;

- vitally important information. The users of social networks react emotionally to the information relating to their basic needs (according to Maslow's pyramid), events that significantly affect or may affect their lives, etc;

- usefulness of the information. Users share the materials that may be useful, valuable and practical. Usually, this information is posted and shared in the form of lists and short notes, rolls or instructions;

- the latest information. The content that publishes exclusive information first usually gains considerable popularity among the users of social networks [4, p. 51].

However, considering the factor of content peculiarities together with another factor - the peculiarities of the audience, namely psychological fea- 
tures that encourage people to share some information, the most important factor of information virality is its ability to activate the audience emotionally [5, p. 108]. Only those materials that cause the state of arousal and readiness for action or encourage users to emotional activity have a chance to become viral sharing online. This is explained by the psychological state of a person caused by different emotions: positive emotions, such as inspiration, a great joy, laughter, induce us to share impressions. They also increase the activity and stimulate the feeling of fear and anger. However, such emotions as sorrow or satisfaction, vice-versa, reduce users' activity.

In addition, the content sharing in social networks is also influenced by another feature of users' psychology - the desire to get attention from their virtual friends via "like", thanks, and other methods of post appraisals in social networks, that is why users will share only that information which is likely to attract his audience.

The popularity of content also depends significantly on the peculiarities of the very social networks: the hours of users' greatest activity on the net, the algorithms for ranking posts in the news line, etc. As the services of web analytics show, for example, in Facebook the traffic begins to grow from 9 am and falls by $4 \mathrm{pm}$. The best time for publishing materials in this network is from $1 \mathrm{pm}$ to $4 \mathrm{pm}$ on weekdays. As the studies show, the most clickable links appeared to be those which were posted in Facebook on Wednesday at $3 \mathrm{pm}$. Similar data for Twitter indicate that one can get the highest amount of clicks on this network on Monday between $1 \mathrm{pm}$ and $3 \mathrm{pm}$. The Twitter audience is the most active between 9 am and $3 \mathrm{pm}$, but after $8 \mathrm{pm}$ the publication of content in the network is the least effective [6]. The VKontakte network, which is popular in Ukraine, becomes most effective for posting information is after $7 \mathrm{pm}$ and between $1 \mathrm{pm}$ and $3 \mathrm{pm}$ [7]. However, one should also take into consideration the peculiarities of the target audience and the subject area of the resource that can also affect user's activity in social networks.

Besides, some networks have their own algorithm for ranking posts in the news line, so, it is important to mind this fact while creating the virality content. For example, Facebook often changes the ranking factors and one of the recent changes, reported by the company in 2014, was the creation of an algorithm based on trending topics and the speed of user's interaction with the post [8]. Also this network continues taking into account the ranking factors from a previous mechanism EdgeRank: 
- affinity (the frequency of interaction with certain users);

- type of action (e.g. a comment makes the post more valuable than "like");

- time of publication (new posts weigh more) [9].

Most social networks are likely to abandon the chronological news line in the nearest future. It was already announced by such popular networks as VKontakte and Instagram, so we may also consider this peculiarity of social networks as important factor of content virality.

In considering the issue of creating the virality content, it is worth mentioning not only the tools but also the goal of sharing such viral information. With the help of virality content media, companies, organizations can achieve not only extreme popularity, better SMM indicators or conversion. Virality content makes it possible to manipulate the audience. An incredible amount of information that appears in the news line in the internet, satiety of information space makes the users focus on the choices of other people interested in the content, and not to look for the best posts in the net on one's own. As J. Berger notes, consequently the lists of the most popular content can generate topics for wide discussion. For example, the more people saw and shared an article about financial reform, the more likely that others will get the belief that financial reform deserves more attention from the state than the reform of environmental protection, even if the core of financial reform is not as important as environmental [5, p. 96].

Imposing certain topics to the audience for discussion or diverting attention from important, but problematic issues with the help of the factors of virality content may be regarded as a method of manipulating public consciousness that makes it possible to achieve the desired response to the information, for example, in terms of hybrid warfare.

In order to determine the factors of virality content of Ukrainian media in social networks, we have analyzed the Facebook pages of the three media that are the most popular on this network according to the rating of an international company in the segment of social marketing Socialbakers [10]: "Ukrayinska Pravda", "Hromadske TV" and "TSN" in the period from April 18 to 24, 2016. These three media have more than 500 thousand readers. Overall we have analyzed 683 pages of posts on these media.

The results of our analysis were considered at in terms of such groups of factors as type of content, date and time of publication and the subject area of messages. 
Type of content that is being shared in social networks has appeared to be the one of the most important factors of post popularity. The pages of media under analysis most frequently contained published links to the web site with a short message about the content of the article. Thus, for example, all the materials on "Ukrayinska Pravda" pages were the links to the site with the full text; the "TSN" page besides publications with links, several times there were only photos posted; "Hromadske TV" contains various types of content: photo, video, link to the site, gif-animation, etc. And it turned out that the posts from "Hromadske TV" on the same subjects as in other media, published at the same time, appeared to be the most popular and most shared among users. For example, the news about a new video of "Okean Elzy" was published on "TSN" at 11:16, and received 631 likes, 7 comments and 147 shares. The news was actually the link to the TSN website, where everybody could watch the very video. At the same time, the same news on the "Hromadske TV" was published at 12:08, and received 7,400 likes, 77 comments and 4,296 shares. The number of shares is nearly 30 times higher than the number of shares on TSN, probably due to the format of the post. "Hromadske TV" published the very clip on its page in the social network, not just the link to the site with this news. The mobility of users on social networks and the specificity of the services having entertainment purposes (communication, viewing photos, videos, listening to music) cause the greater popularity of the content that can be viewed immediately in the news line of social network. This is the reason of great popularity of other such posts on various topics (pictures of V. Klychko riding a bicycle, photos from the ceremony of lighting the Olympic flame in Greece, video of Kyiv from the bird's-eye view, photos of tulips exhibition in Kyiv, video dedicated to $26^{\text {th }}$ anniversary of the Hubble telescope, etc. - they all received 2,000-6,000 likes).

In addition to the format of the material, the determining factor of content popularity in social networks is the subject matter of information. According to our analysis, the most popular posts (Fig. 1) on the media pages in Facebook are the following: $24,7 \%$ - on policy and public management; $16.8 \%$ - the war in the east of Ukraine; $14.2 \%$ - the culture; $14.2 \%$ basic needs (education, health, material well-being, improvement of the city, etc.); $11.3 \%$ - on world politics; $11.3 \%$ - cognitive information, sports, space, etc.; $7.5 \%$ - tragic events in Ukraine and the world. 


\section{The subject area of popular materials on the pages of Ukrainian media in Facebook}

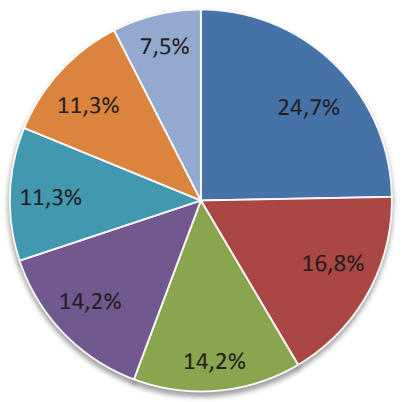

- Politics and public management

- War in the east of Ukraine

Basic needs

- Culture

- World politics

- Cognitive information

Tragic events

\section{Fig. 1. The subject area of popular materials on the pages of Ukrainian media in Facebook}

According to international studies, the most viral is the content which evokes positive emotions. However, our research shows that in Ukraine, the highest percentage of top posts is about the war and politics and under current conditions such posts do not arouse the sense of joy and satisfaction of the audience. The dominance of negative emotions in the media of social networks can explain by the transformation of the sense of materials on given topics into the sphere of vital needs (according to the Maslow pyramid); under conditions of a hybrid warfare, most people see even politics through the lens of survival, security, being able to provide themselves with food, heat and other urgent resources. Among the most popular posts are those that have been commented by the most active users, they are also dedicated to the politics:

- "Klychko says he "decided to ride a bike to work and in the downtown" - 521 comments.

- "The new government is preparing a new rise of prices" - 414 comments.

- "If you haven't come to the session - pay a fine" (about MPs) 280 comments.

- "Russian special squad soldiers Alexandrov and Yerofeyev are found guilty and sentenced to 14 years in prison" -240 comments. 
- "Hroisman increased MPs' salaries on the same day when they supported his candidacy for prime minister" - 229 comments.

And since, according to the algorithm of ranking information in the Facebook news line, a comment is more valuable for a post than "like", the information of such subject matter becomes the most popular.

The most shared posts on media pages in the social network were the following:

- The new video of "Okean Elzy" - 4,296 shares.

- When to expect the visa-free regime - 1,512 shares.

- How does Kyiv look like from the bird's-eye view - 1,268 shares.

- An Easter township is opened in the center of Kyiv - 1,109 shares.

- Travelers created an interactive Google-map and marked there the most interesting and outstanding places in Ukraine - 829 shares.

All the posts, the most popular for sharing, cause joyful emotions and concern good news. This fact confirms the idea that the audience shares mostly positive data on their pages, expecting to receive some encouragement or gratitude from their friends in social networks - "like", share, etc.

The highest number of likes received those popular posts the basic idea of which is approved by users, they refer positively to that event:

- The new video of "Okean Elzy" - 7,400 likes.

- "Klychko says he "decided to ride a bike to work and in the downtown" - 6,300 likes.

- "Adidas company stops using plastic bags" - 5,300 likes.

- "An Easter township is opened in the center of Kyiv" - 4,900 likes.

- "Lviv wants to ban concerts and shows of Ukrainian and foreigners who support Russian aggression and propagate separatism" - 4,000 likes.

However, "likes" for ranking posts in Facebook are not as valuable as comments and "shares".

Besides the content and subject forms, the date and time of posting materials can also affect the popularity of information in social network. But the importance of this factor depends primarily on the characteristics of the social network, its algorithm for constructing user's news line, etc. For example, for social networks with chronological news line, the time of information posting may be crucial to its virality. But most social networks have abandoned this type of news line and rank users' posts using more complex algorithms. Therefore, according to the analysis of Ukrainian media pages in Facebook, there is no clearly evident link between the popularity of a material and the 


\section{Husak Olviia, Fiialka Svitlana}

time of its publication. The materials that appear in the news line most often are those which have the highest interaction with users - they comment it, share, like, regardless of the time of posting. It should be noted that the users become most active in the evening, so the posts published in the afternoon and later usually attract more attention of the audience.

\section{Technical university students' media literacy in social networks}

Modern society is a society of social networks. They provide an opportunity for all to create a profile with photos and information about themselves, exchange messages, change a status, post messages on the own and others' walls, upload photos and videos, create communities of interest and even earn real or virtual money. Social networks provide contact with virtual friends 24 hours a day 7 day a week and create understanding of the world. However, the modern people do not always think about the influence of social networks on their beliefs, decisions, deeds. They are not always critical about information in social networks and do not pay attention why certain information has been included in a message, what has not been included, what the key ideas are, and how such ideas affect them? Moreover, along with the emergence of social networks individuals are expected not only to consume but also produce, share and criticize digital contents [11, pp. 834-843; 12]. So, we always must understand that our messages have an impact as well as clearly articulate our thoughts to avoid misunderstanding.

Media literacy has crucial influence on all levels of education, including higher education. The last one, "once a bastion for traditional instruction, has begun a transition to media-based teaching" [13].

To become media literate responsible citizen, students need media education, namely developing expertise with the increasingly sophisticated information, affecting the way they think, feel, and behave. According to G. Gerbner [14], the goal of media education is the formation of a broad coalition to enhance the freedom and diversity of communication, to develop a critical understanding of the media as a new approach to liberal education. A. Fedorov [15] considers media education to be "a process of personal development with the help and on the material of mass media (media) in order to form a culture of communication with the media, creative, communicative abilities, critical thinking, the ability to fully perceive, interpret, analyze and evaluate media texts, learning different forms of expression with the help of media technology, but at the same time he stresses that 
there is no single and only theory of media education in the world." Being media educated requires critical thinking skills from future professional that empower them make socially responsible decisions in workplace [16].

J. Share [17] has categorized the different approaches to media education to fit into four different areas. These are the protectionist approach, media arts education, media literacy movement, and critical media literacy. The protectionist approach views audiences of mass media as dupes of the media, vulnerable to cultural, ideological or moral influences, and needing protection by education. The media arts education approach focuses on creative production of different media forms by learners. The media literacy movement is an attempt to bring traditional aspects of literacy from the educational sphere and apply it to media. Critical media literacy is defined as an educational response that expands the notion of literacy to include different forms of mass communication, popular culture, and new technologies. It deepens the potential of literacy education to critically analyze relationships between media and audiences, information, and power. Along with this mainstream analysis, alternative media production empowers students to create their own messages that can challenge media texts and narratives [18, pp. 59-69].

$H$. Jenkins et al. [19] suggest that the media literacy skills required for participation in this new world are all essentially social skills, including: play, performance, simulation, appropriation, multitasking, distributed cognition, collective intelligence, judgment, transmedia navigation, networking, and negotiation.

Media literacy on the level of higher education includes the ability to notice propaganda or recognize fake, bias, spin, misinformation, the ability to seek information in various sources and types of media, synthesize it, reflex, knowledge of how media messages shape our culture and society, mechanisms of destructive media information influence, theory of reasoning, understanding how Internet and mobile technologies affect personality; understanding the functioning of the media space, knowledge of media owners.

Social networking sites such as Facebook, Twitter, image and video sharing sites (e.g., Facebook, YouTube, Instagram), promote proactive participation and contribution, and diverse interactions [20]. But Stanford's report summary states, that "our 'digital natives' may be able to flit between Facebook and Twitter while simultaneously uploading a selfie to Instagram and texting a friend. But when it comes to evaluating information that flows through social media channels, they are easily duped" [21]. As M. Lynch, 
a philosopher who studies technological change, observed the Internet as "both the world's best fact-checker and the world's best bias confirmer often at the same time" [22]. The luck of media literacy may widen existing society divides whiele creating new barriers which impede engagement with and participation in society [23, p. 42].

\section{Quantitative data analysis}

The questionnaire had ten closed ended items, which dealt with the regular use of social networks among the sample population $(\mathrm{n}=1058)$ (table 1).

Percentage of responses to closed ended items

\begin{tabular}{|c|l|c|c|c|c|c|c|}
\hline No & \multicolumn{1}{|c|}{ Item } & $\begin{array}{c}\text { Strongly } \\
\text { Disagree }\end{array}$ & Disagree & Neutral & Agree & $\begin{array}{c}\text { Strongly } \\
\text { Agree }\end{array}$ & $\begin{array}{c}\text { Not } \\
\text { Responded }\end{array}$ \\
\hline 1 & \multicolumn{1}{|c}{2} & 3 & 4 & 5 & 6 & 7 & 8 \\
\hline $\mathbf{1}$ & $\begin{array}{l}\text { Do you use social } \\
\text { networks for } \\
\text { your educational } \\
\text { purposes? }\end{array}$ & 8.60 & 8.22 & 9.74 & 62.29 & 9.64 & 1.51 \\
\hline $\mathbf{2}$ & $\begin{array}{l}\text { Are you joining } \\
\text { social networking } \\
\text { groups that have } \\
\text { to do with the } \\
\text { direction of your } \\
\text { training? }\end{array}$ & 23.25 & 10.30 & 19.19 & 19.09 & 27.98 & 0.19 \\
\hline $\mathbf{3}$ & $\begin{array}{l}\text { Is it fun to read } \\
\text { posts about technic } \\
\text { in social networks? }\end{array}$ & 9.28 & 11.72 & 13.43 & 44.56 & 21.01 & 0 \\
\hline $\mathbf{4}$ & $\begin{array}{l}\text { Are you joining } \\
\text { social networking } \\
\text { groups that discuss } \\
\text { political topics? }\end{array}$ & 19.84 & 31.07 & 17.34 & 23.75 & 7.19 & 0.81 \\
\hline $\mathbf{5}$ & $\begin{array}{l}\text { Is it fun to argue } \\
\text { with social networks } \\
\text { members? }\end{array}$ & 34.17 & 24.02 & 21.58 & 34.09 & 5.32 & 0,82 \\
\hline $\mathbf{6}$ & $\begin{array}{l}\text { Do you react on } \\
\text { insults in social } \\
\text { networks? }\end{array}$ & 26.71 & 17.59 & 5.01 & 37.93 & 12.76 & 0 \\
\hline $\mathbf{7}$ & $\begin{array}{l}\text { Do you always } \\
\text { critically analyze } \\
\text { information in } \\
\text { social networks? }\end{array}$ & 0 & 4.60 & 18.04 & 49.85 & 27.51 & 0 \\
\hline
\end{tabular}


Social media influence on public opinion and youth behavior

Ending of Table 1

\begin{tabular}{|c|l|c|c|c|c|c|c|}
\hline 1 & \multicolumn{1}{|c|}{2} & 3 & 4 & 5 & 6 & 7 & 8 \\
\hline $\mathbf{8}$ & $\begin{array}{l}\text { Do you tend to } \\
\text { share not verified } \\
\text { information? }\end{array}$ & 38.75 & 15.68 & 19.76 & 18.14 & 6.16 & 1.51 \\
\hline $\mathbf{9}$ & $\begin{array}{l}\text { Do you always trust } \\
\text { citations? }\end{array}$ & 12.04 & 14.97 & 13.45 & 46.13 & 8.98 & 4.43 \\
\hline $\mathbf{1 0}$ & $\begin{array}{l}\text { Do you think it } \\
\text { is necessary to } \\
\text { implement media } \\
\text { literacy courses in } \\
\text { your university? }\end{array}$ & 15.75 & 16.45 & 12.87 & 39.99 & 13.34 & 1.60 \\
\hline
\end{tabular}

The results of the survey indicate that $71.93 \%$ of the students use social networks for their educational purposes. At the same time, $16.82 \%$ does not do this. Only $47.07 \%$ students are enrolled in social networking groups that have to do with the direction of their training, although $65.57 \%$ of the respondents likes to read posts about technic in social networks. Meanwhile only $30.94 \%$ of students are joining social networking groups that discuss political topics. $39.41 \%$ of the respondents are sure that it fun to argue with social networks members, $50.69 \%$ of the students usually react on insults in social networks. $77.36 \%$ of the respondents suppose that they always critically analyze information in social networks. But $24.30 \%$ responded they tend to share not verified information, and $55.11 \%$ of the students always trust citations. Thus, although nearly $80 \%$ believe that they critically evaluate information on the social networks, it is alarming that more than half of the students respond to insults in social networks, almost a quarter of students share unverified information, and more than 55\% are accustomed to trusting quotes without thinking about their authenticity.

\section{Qualitative data analysis}

Categorization of responses to open ended item "Why do you use or do not use social networks for your educational purposes?"

$71.93 \%$ of the students use social networks for their educational purposes. The reasons put forth are categorized into: (1) social networks are user friendly, (2) information is relevant and interesting, (3) vast information available, (4) information being interactive and personalized, (5) the opportunity to discuss professional information and share it, (6) the opportunity to connect with their lecturer, (7) the opportunity to join a group on 


\section{Husak Olviia, Fiialka Svitlana}

professional interests. However, $16.82 \%$ students did not support the idea to use social networks for their educational purposes and emphasized that social networks: (1) do not always give reliable and authentic information, (2) distract from learning, (3) give simplified and not verified information, (4) give biased information, (5) offer repetitive information, (6) offer unsuitable information, (7) give unsystematized information.

Categorization of responses and their percentage distribution to open ended item "Why are you joining or are not joining social networking groups that discuss political topics?"

$30.94 \%$ of students are joining social networking groups that discuss political topics. The reasons are following: (1) enjoy the criticism of authorities, (2) believe that they can influence political processes by expressing their opinion, (3) get information about the political situation in the country, (4) unite around political forces, which they sympathize with, (5) leave angry comments. But $50.91 \%$ of the respondents are not joining social networking groups that discuss political topics. The reasons were following: (1) I do not want to, (2) I would like to, but do not have the time, (3) I am irritated by any policy.

Categorization of responses to open ended item "Why do I react or do not react on insults in social networks?"

$50.69 \%$ of the students react on the insults in social networks. The reasons put forth are categorized into: (1) I cannot restrain myself; (2) I want to win the dispute, (3) I want to punish the offender, (4) I like to insult people on the Internet. But $44.30 \%$ of the respondents do not react on insults in social networks. The reasons were following: (1) everyone has the right to their opinion, (2) I know that, responding to insults, I provoke trolls, (3) I do not read any comments.

Categorization of responses to open ended item "Why do I always (do not always) critically analyze information in social metworks?"

$77.36 \%$ of the students suppose that they always critically analyze information in social networks. The reasons: (1) I do not want to be deceived, (2) I like to unmask the authors of the posts, (3) I am an educated person and should perceive information responsibly. Only $4.60 \%$ of the student accept they do not always critically analyze information in social media. The reasons were following: (1) I have no time, (2) I am sure that my friends share only verified information, (3) I have no clue how to analyze information critically, (4) I think, it is not important. 


\section{Social media influence on public opinion and youth behavior}

\begin{tabular}{|c|c|c|}
\hline \multirow{4}{*}{ 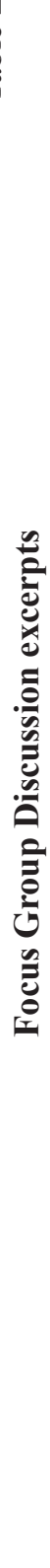 } & 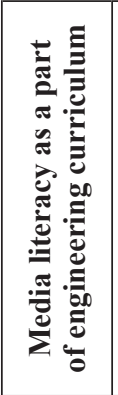 & 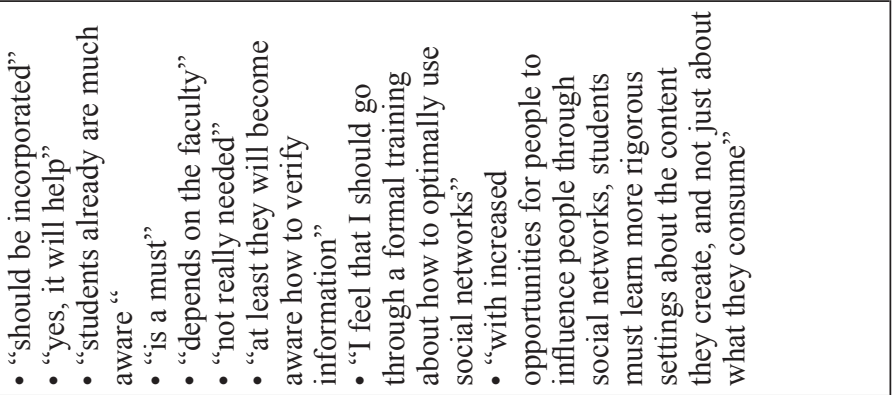 \\
\hline & 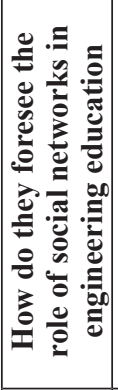 & 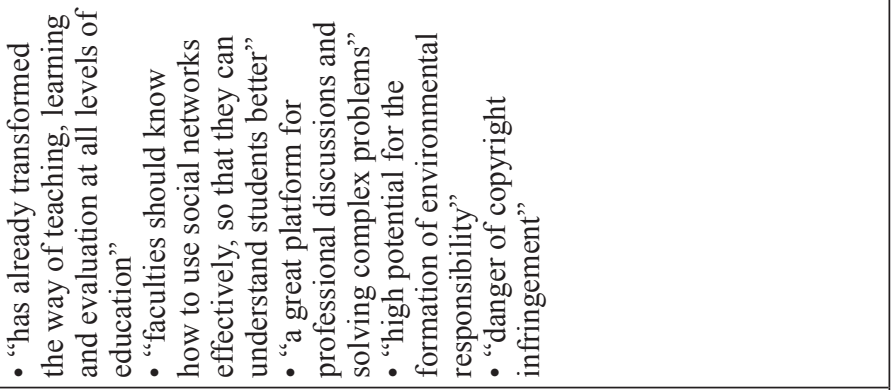 \\
\hline & 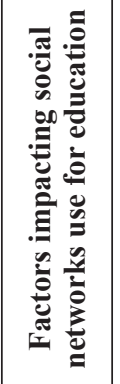 & 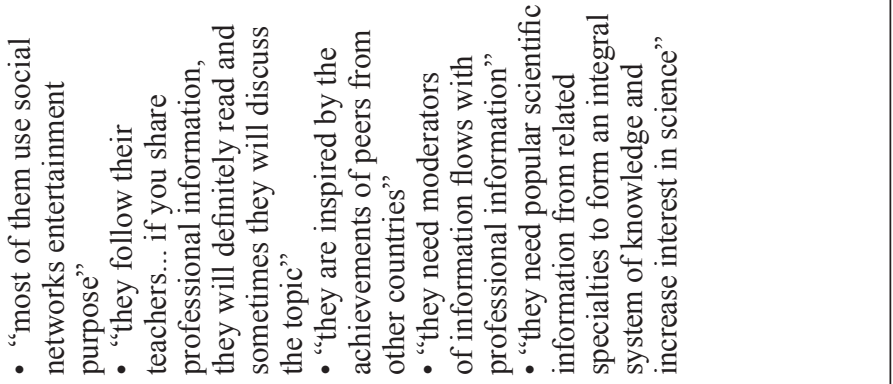 \\
\hline & 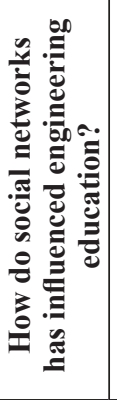 & 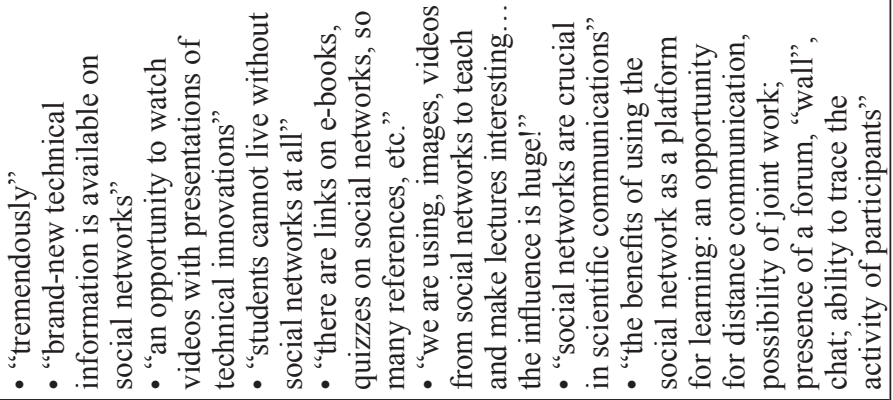 \\
\hline
\end{tabular}


Categorization of responses to open ended item "Do you think it is necessary (not necessary) to implement media literacy courses in your university?"

$53.33 \%$ of the students suppose it is necessary to implement media literacy courses in university. The reasons put forth are categorized into: (1) it will help me to identify false information, (2) I do not have enough information on how to behave in social networks, (3) it is important how to use social networks in the right way, (4) it is important for my career. But $32.2 \%$ of the students think it is not necessary to implement media literacy courses, because: (1) I have enough knowledge, (2) media literacy is required only for journalists, (3) these knowledges will not help me in professional activity, (4) media literacy is a pseudoscience.

Focus Group Discussion supported the hypothesis of increasing role of media literacy in engineering curriculum (table 2).

Based on the results of the survey, focus group discussion and own teaching of the theory of mass communication, we summarized the basic media competencies that students need while working on the social networks (table 3 ).

Table 3

Basic media competencies while working on a social network

\begin{tabular}{|c|c|c|}
\hline $\begin{array}{l}\text { Understanding messages } \\
\text { (how they work and } \\
\text { influence on individuals } \\
\text { and society) }\end{array}$ & \begin{tabular}{|} 
Using social networks \\
(in professional \\
activities and achieving \\
own goals)
\end{tabular} & $\begin{array}{c}\text { Communication } \\
\text { (interaction) }\end{array}$ \\
\hline $\begin{array}{l}\text { 1. How do they affect my } \\
\text { personal well-being and } \\
\text { well-being of my country? } \\
\text { 2. How do they strengthen } \\
\text { or weaken society's } \\
\text { democratic structures? } \\
\text { 3. How do I decode } \\
\text { massages I get? } \\
\text { 4. What actions do I get } \\
\text { impelled by the messages? }\end{array}$ & \begin{tabular}{|l} 
1. How true and reliable \\
information is? \\
2. Do not I look at \\
message from just one \\
perspective? \\
3. Can I identify facts \\
versus opinions? \\
4. How much do I \\
control the level of \\
access to personal \\
information? \\
5. Do not I violate the \\
law of intellectual \\
property?
\end{tabular} & $\begin{array}{l}\text { 1. Do I need this information? } \\
\text { 2. Do other people need } \\
\text { information that I share? } \\
\text { 3. How might other people } \\
\text { understand or interpret this } \\
\text { message differently from me? } \\
\text { 4. What arguments do I use to } \\
\text { support my opinion? } \\
\text { 5. Am I polite in social network? } \\
\text { 6. How do I react to hate } \\
\text { speech in social networks? } \\
\text { 7. Do I know a foreign } \\
\text { language at a level sufficient } \\
\text { for communication? } \\
\text { 8. What values and lifestyle do } \\
\text { I promote? } \\
\text { 9. What feedback do I expect } \\
\text { from an audience? }\end{array}$ \\
\hline
\end{tabular}




\section{Conclusions}

The results of the study showed that in the Ukrainian context, given the political situation and hybrid warfare, the most popular content in social networks is on burning topics - politics, war, basic life needs; in the form of video, photos or short text without links to external resources for full information; posted in the afternoon or later. The audience most often "likes" the content, which causes positive emotions, however, according to the principles of ranking information in the news line of Facebook, the posts receive the biggest coverage of the audience when they are shared and commented by users. So, to increase the information virality in social networks the publication must encourage people to discuss and comment (include questions or call in the text, to have a bit conflicting implication), correspond to the subject area of popular topics for Ukrainians, and for sharing the material enable the user to get reaction from friends for his "repost", for example, owing to the usefulness of the material, emotions of joy, pride, exaltation and importance of information to a wide audience.

In addition this study was conducted to analyze the attitude about role of social networks among technical students and estimate the need social networks media literacy in their curriculum.

The present study revealed that students are aware of the disadvantages attached to social networks as a reference source in terms of vulnerability to misuse and unreliability resource of information.

The Focus group discussion experts further the assumption that students are getting more and more influenced by social networks as a ready source of information. The teachers support the idea of incorporating its basic training in curriculum. The faculties themselves understood that they should receive a formal training about how to optimally use social networks for better teaching activities.

Due to gathered qualitative data, we can safely determine that social networks use amongst engineering students is a part of their daily routine. Most of the students actually depend on it for retrieval of information. We can conclude that students tend to overestimate the influence of social networks on beliefs and behavior of others and underestimate their influence on themselves. Modern youth needs higher education with solid media education backgrounds combined with professional training. We propose not so much to offer a specific course on media literacy, but to democratize the technical schools themselves and to form critical thinking through 
the whole educational process. Because critical thinking cannot be taught through one course. There should be a systematic approach.

\section{References:}

1. Dementiy D. (2013) Kak sozdavat viralnyy kontent dlya sotsialnykh setey: 7 sovetov [How to create viral content for social networks: 7 tips]. TexTerra. Retrieved from: http://texterra.ru/blog/kak-sozdavat-viralnyy-kontent-dlya-sotsialnykh-setey-7-sovetov.html (accessed 18 May 2016). (in Russian)

2. MetkalfB.(2014)ZakonMetkalfasorokletspustyaposlerozhdeniyaEthernet [Metcalfe's Law after 40 Years of Ethernet]. Otkrytye Sistemy. Retrieved from: http://www.osp.ru/os/2014/01/13039684/ (accessed 18 May 2016). (in Russian)

3. Konnikova M. (2014) The six things that make stories go viral will amaze, and maybe infuriate, you. The New Yorker. Retrieved from: http://www.newyorker.com/ online/blogs/elements/2014/01/the-six-things-that-make-stories-go-viral-willamaze-and-maybe-infuriate-you.html?utm_source=tny\&utm_campaign=generalsocial\&utm_medium=facebook (accessed 18 May 2016).

4. Husak O. (2014) Rol sotsialnykh merezh u roboti redaktora zadlya populyaryzatsiyi saytu internet-ZMK [The role of social networks in the editor's work for popularization the online-media site]. Visnyk Knyzhkovoyi palaty, no. 7 (216), pp. 48-51. (in Ukrainian)

5. Berger J. (2014) Zarazitelnyy. Psikholohiya sarafannoho radio. Kak produkty i idei stanovyatsya populyarnymi [How products and ideas become popular]. Moscow: ACT, Mann, Ivanov i Ferber. (in Russian)

6. Hordienko M. (2016) Kohda luchshe publikovat posty v sotsialnykh setyakh [Best Times To Post On Social Media]. Blog digital-ahentstva Fresh IT. Retrieved from: https://freshit.net/blog/internet-marketing/kogda-luchshe-publikovat-postyv-socialnyx-setyax/ (accessed 18 May 2016). (in Russian)

7. Zorab R. (2012) Luchshee vremya dlya postinha vo VKontakte ili kak sobrat bolshe laykov [Best Times To Post On Vkontakte or how to get more likes]. Cossa. Retrieved from: http://www.cossa.ru/155/23989 (accessed 18 May 2016). (in Russian)

8. Owens E., Vickrey D. (2014) News Feed FYI: Showing More Timely Stories from Friends and Pages. Facebook Newsroom. Retrieved from: http://newsroom. $\mathrm{fb}$.com/news/2014/09/news-feed-fyi-showing-more-timely-stories-from-friendsand-pages/ (accessed 18 May 2016).

9. Silaeva D. (2014) Chto stalo s alhoritmom ranzhirovaniya Facebook [What happened with Facebook Rank Algorithm]. Cossa. Retrieved from: http://www.cossa.ru/152/74285/ (accessed 18 May 2016). (in Russian)

10. RBK-Ukraina (2015) Socialbakers vyznachyla top-10 naybilsh chytanykh ukrayinskykh ZMI u Facebook [Socialbakers have identified top 10 most-read Ukrainian media in Facebook]. Retrieved from: https:/www.rbc.ua/ukr/news/ socialbakers-opredelila-top-10-samyh-chitaemyh-1448887542.html (accessed 18 May 2016). (in Ukrainian)

11. Koc M., Barut E. (2016) Development and validation of New Media Literacy Scale (NMLS) for university students. Computers in Human Behavior, no. 63 , pp. $834-843$. 
12. Graber D., Mendoza, K. (2012) New Media Literacy Education (NMLE): A Developmental Approach. Journal of Media Literacy Education, no. 4 (1), pp. 82-92.

13. Strawser M. (Ed.). (2017) Enhancing the twenty-first-century classroom. London.

14. Gerbner G. (1995) Educators Activists Organize to Promote Media Literacy in U.S. The New Citizen, no. 2 (2).

15. Fedorov A. (2010) Slovar" terminov po mediaobrazovaniyu, mediapedagogike, mediagramotnosti, mediakompetentnosti [Dictionary of terms for media education, media pedagogy, media literacy, media competence]. Taganrog. (in Russian)

16. European Commission (2009) Commission Recommendation on Media Literacy in the Digital Environment for a More Competitive Audiovisual and Content Industry and an Inclusive Knowledge Society. Retrieved from http://eur-lex.europa.eu/legalcontent/EN/TXT/PDF/?uri=CELEX:32009H0625\& from=EN. European Commission 2009. (accessed 18 September 2017).

17. Share J. (2002) Media Literacy is Elementary: Teaching Youth to Critically Read and Create Media (Rethinking Childhood). New York: Peter Lang.

18. Kellner S., Douglas J. (2007) Critical media literacy is not an option. Learning Inquiry, no. 1(1), pp. 59-69.

19. Jenkins H., Purushotma R, Clinton K. Weigel M., Robinson (A). (2006). Confronting the Challenges of Participatory Culture: Media Education for the 21st Century. New Media Literacies. Retrieved from http://newmedialiteracies.org/ (accessed 18 September 2017).

20. McLoughlin C., Lee M. J. W. (2007) Social software and participatory learning: Pedagogical choices with technology affordances in the Web 2.0 era. Paper presented at the ASCILITE, Singapore.

21. Brook D. (2016) Stanford researchers find students have trouble judging the credibility of information online. Stanford. Retrieved from https://ed.stanford.edu/ news/stanford-researchers-find-students-have-trouble-judging-credibility-information-online (accessed 11 September 2017).

22. Lynch M. (2016) Googling is Believing: Trumping the Informed Citizen. New York Times, March 9. Retrieved from http://opinionator.blogs.nytimes. com/2016/03/09/googling-is-believing-trumping-the-informed-citizen/ (accessed 18 September 2017).

23. Leaning M. (2009) Issues in information and media literacy. Santa Rosa. 